\title{
SALIVARY GLAND STRUCTURE AND FUNCTION IN EXPERIMENTAL DIABETES MELLITUS
}

\author{
Leigh C. Anderson \\ Department of Oral Biology, University of Washington School of Dentistry, Seattle, Washington, USA
}

\section{SUMMARY}

- While salivary secretion is not initiated by circulat ing hormones, there are significant endocrine influences on the development, structure and function of salivary glands. Experimental animal models of diabetes mellitus have been used to study all aspects of diabetic pathophysiolog)!. There is now a considerable body of evidence demonstrating that the effects of diabetes on rodent salivary glands are related as much to the indirect consequences of insulin insufficiency on the circulating levels of other hormones, and autonomic nerve function, as to the direct actions of insulin. In addition to their exocrine functions, salivary glands also play an endocrine role. Rodent submandibular glands, in particular, are a rich source of biologically active polypeptides, which are synthe sized in the granular ducts. Although many of these polypep tides are released into both the blood and the saliva, their physiological functions have yet to be fully explored. Never theless, the disruption of submandibular gland endocrine function has been postulated to contribute to the pathology observed in diabetic animals. (BiomedRev 1998; 9: 107-119)

Received for publication 15 May 1998 and accepted 10 November 1998.

Corespondence and reprint requests to Dr Leigh C. Anderson. Department of Oral Biology. Box 357132. UniversityofWashington. Seattle. WA98195. USA.Tel: 1 (206) 5435 477. Fax: 1 (206) 6853 162. Email: copains'«)u. Washington.edu

\section{INTRODUCTION}

- The function of most glands in the digestive tract is dependent, at least in part, on hormonal stimulation, but salivary gland function has been regarded as primarily, if not exclusively, under the control of autonomic nerves. Nonetheless, while salivary secretion is not initiated by circulating hormones, there are significant endocrine influences on the development, struc ture and function of salivary glands. Moreover, salivary glands have been postulated to have endocrine functions of their own. Rodent submandibular glands (SMG), in particular, synthesize and release into the blood a variety of biologically active po lypeptides for purposes that remain to be fully elucidated.

\section{- $\quad$ Diabetes mellitus}

The term diabetes mellitus refers to a group of heterogeneous disorders that share the common feature of glucose intolerance, and the key defect that leads to the onset of insulindependent diabetes mellitus (IDDM, type I) is an autoimmune destruction of ( 3 cells in the pancreas and, as a consequence, a loss of insulin producing capacity. In contrast, non-insulindependent diabetes mellitus (N1DDM, type II), which occurs most commonly in adults, is characterized by a derangement of insulin secretion and the development of insulin resistance. The binding of insulin to its receptor rapidly directs metabolism toward anabolic and away from catabolic pathways, thereby promoting glucose transport and carbohydrate metabolism, fatty acid synthesis, amino acid transport, proteins synthesis, 
and mRNA synthesis. Experimental animal models of human diabetes mellitus have been used to study all aspects of diabetic pathobiology, but the specific effects of diabetes in any given tissue, including the salivary glands, are related as much to the indirect consequences of insulin insufficiency on blood chemistry, circulating levels of other hormones, and autonomic nerve function, as to the direct actions of insulin.

\section{- $\quad$ Animal models of diabetes mellitus}

The diabetogenic effects of alloxan were first reported in 1943 by Dunn and colleagues, and its cytotoxic effects result from the intracellular generation of reactive compounds such as superoxide anion and hydroxyl radicals (1). At least in the rat, alloxan also displays a significant degree of extrapancreatic, hepatic and renal, toxicity, and because of this streptozotocin has largely replaced alloxan as the diabetogenic agent of choice for this species (2). Both alloxan- and streptozotocin-diabetic animals exhibit polydypsia, polyuria and glycosuria, but unlike human diabetes mellitus the hyperglycaemia is seldom accompanied by ketoacidosis. As a result, alloxan- and streptozotocin-treated animals can usually be maintained in a stable diabetic state indefinitely. A spontaneous animal model of IDDM. the BioBreeding (BB) Laboratories Wistar rat, has also been used to study the dynamic physiological changes that occur in diabetes (3). These animals develop a syndrome that closely resembles the human form of the disease, both in time of onset and severity. Other spontaneous models of diabetes include the genetically diabetic $(d b / d b)$ and the non-obese diabetic (NOD) mice. The $d b / d b(\mathrm{C} 57 \mathrm{BL} / \mathrm{KsJdb})$ mouse is a model ofNIDDM, and hyperglycaemia prevails in company with normal or sometimes even elevated circulating levels of insulin (4). The NOD mouse, on the other hand, appears to be more suitable for the study of autoimmune salivary gland diseases, such as $\mathrm{Sj}$ ugren's syndrome (5).

\section{SALIVARY GLAND STRUCTURE AND EXOCRINE FUNCTION IIII DIABETES MELLITUS}

- The gross morphological effects of diabetes on the salivary glands have been well documented. Initial reports demonstrated that the induction of alloxan diabetes led to a reduction in parotid gland and SMG weights $(6,7)$. Virtually all subsequent studies confirmed these findings (8-21), and with only minor exceptions the SMG was more susceptible than the parotid gland. Insulin treatment reversed the effects of diabetes, and thus diabetes and insulin are generally considered to have parallel effects on salivary gland and body growth. The notable exception was the rat sublingual gland, which was relatively unaffected $(14,20)$. Liu and Lin $(6,7)$ quickly realized, however, that the effects of diabetes on SMG growth were not due to in sulin insufficiency alone. The combination of insulinand growth hormone, for example, was more effective than either hormone alone in reversing the effects of diabetes on the rat SMG. Moreover, diabetes resulted in a decrease in the weights of several endocrine glands, including the thyroid, the adrenal and the pituitary, suggesting that the effects of diabetes on salivary glands might be mediated indirectly through a decrease in the circulating levels of hormones other than insulin.

\section{- Parotidandsubmandibularacinarcellstructureand function}

Early morphological studies indicated that parotid and SMG acinar cell size was reduced in alloxan-diabetic rats (6). Later studies were unable to confirm such changes in short-term, 3-12 weeks duration, streptozotocin-diabetes, but a reduction in SMG acinar cell size was observed in long-term, 4-6 months, streptozotocin-diabetic rats (17). Electron microscopy revealed a variety of pathological changes, including a pooling of secretory material and an increase in the number of autophagic vacuo-les in the rat SMG (17), and the presence of membrane bound cytoplasmic "crystalloids", which appeared to be lysosomal in nature, in the parotid gland $(8,18)$. However, the most striking morphological abnormality found was the accumulation of lipid droplets in the basal regions of serous acinar cells (Fig. 1,2). The appearance of lipid in the parenchymal cells was rapid, beginning within 24 hours after the induction of diabetes, and it persisted indefinitely in the absence of insulin treatment. Little or no lipid was observed in the mucous acinar cells of the sublingual glands, and except in a few intercalated ducts, none was found in ductal cells. While lipid droplets were observed in all three major salivary glands of the rat, its accumulation in the parotid gland was particularly impressive (Fig. 2). On average, 8-10\% of the acinar cell volume was occupied by lipid, but in some instances the lipid displaced most of the intracellular organelles, causing the acinar cells to superficially resemble adipocytes. In frozen sections, the lipid stained with Oil Red $\mathrm{O}$ and calcium li-pase suggesting that it was comprised of neutral lipids, primarily triglycerides (21). Although the increased lipid could not be attributed to any one class, there were changes in fatty acid composition; C18:0 (stearic acid) and C: 18:2co6 (linoleic acid) increased while $\mathrm{C} 18: 1 \mathrm{co} 9$ (oleic acid) and C20:4co6 (arachidonic acid) decreased (22). Why the acinar cells should accumulate lipid in diabetes is unknown, but three possible explanations present themselves: (/) the lipid may serve as a potential source of energy in the absence of glucose transport as it does in cardiac and skeletal muscle $(23,24)$, (//) lipid accumulation may occur consequent to nonspecific endocytosis of excess circulating lipid (25); serum triglyceride levels are elevated in diabetic rats (18), and (///') lipid storage might be enhanced due to a decrease in its utilization for the packaging of secretory proteins. Insulin appears to directly stimulate acinar cell secretory protein synthesis in both the parotid and SMG. Parotid amylase levels were reduced in diabetes and insulin rapidly enhanced amylase and amylase mRNA synthesis (8-11). Similarly, the 


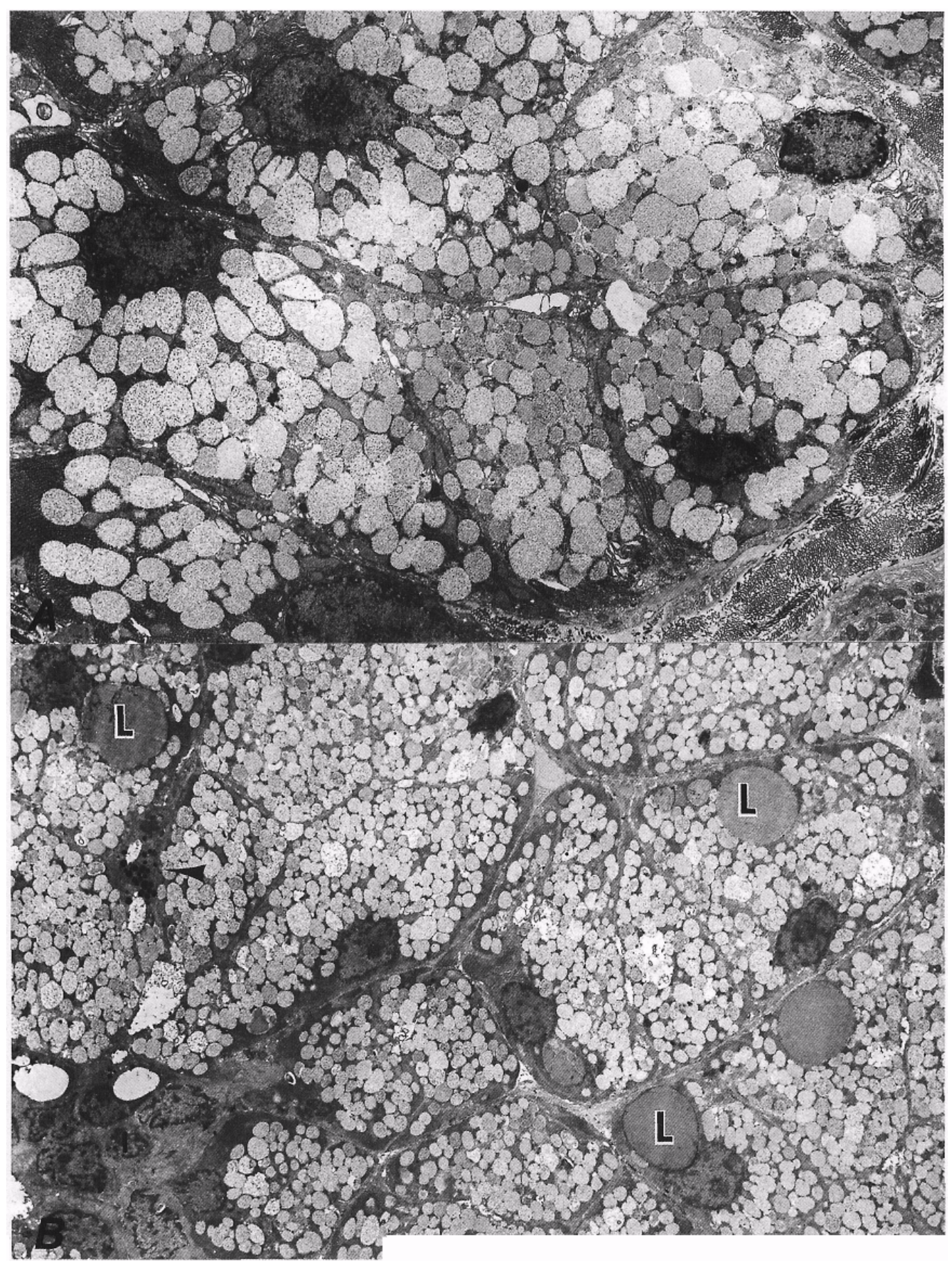

Figure 1. Electron micrograph of the submcmdibiilar gland from a control rat. The acinar cells are relatively uniform in size, and packed with electron-lucent secretorv granules (A). Electron micrograph of the submandibular gland from 3-week streptozotocindiabetic rat. Lipid droplets $(L)$ are present in the acinar cells, but not in intercalated duct cells. Note the small serous-like granules in the cells of the acinar-intercalated duct interface (arrow) (B). x 4400 (A), x 2090 (B).From Ref 13. 


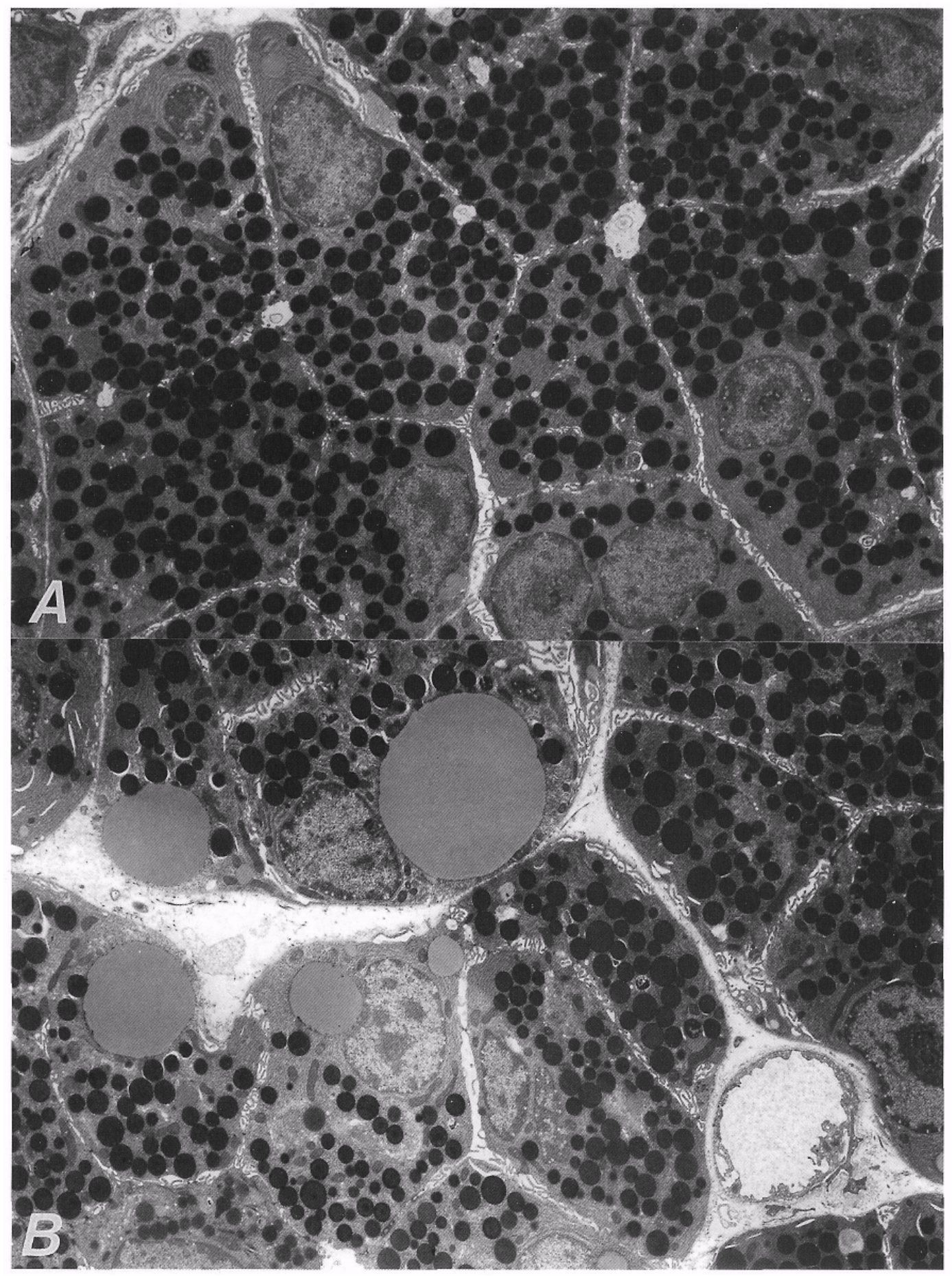

Figure 2. Electron micrograph of the parotid gland from a control rat. The acinar cells are relatively uniform in size, and are packed with electron-dense secretory granules (A). Electron micrograph of the parotid gland from a 3-week slreptoiolocindiabetic rat (B). Lipid droplets of vary ing si:e are present in the basal portions of the acinar cells, x 3500 (A, B). From Ref69. 
activity of acinar cell-derived peroxidase in the SMG was decreased in diabetic rats (13). Insulin treatment in vivo led to an increase in peroxidase activity and a stimulation of amino acid incorporation into proteins. In vitro studies confirmed that insulin rapidly stimulates protein synthesis in the rat SMG (26). The effects of insulin, however, were more specific than a general upregulation of protein synthesis as not all secretory proteins were equally affected by diabetes and insulin (8). Insulin also stimulated the incorporation of glucose into SMG and sublingual gland glycoproteins. The depression of glucose incorporation was correlated with a decrease in the activities of several enzymes involved in the biosynthesis of hexosamines and sialic acid (12,27-30). Conversely, an enzyme involved in the degradation of glycoproteins and glycosaminoglycans, N-acetyI-(3-D-glucosaminidase, was increased in streptozotocin-diabetes, and its activity was depressed by insulin (3 1). Differences in carbohydrate metabolism were also revealed histochemically using glycoconjugate staining (20).

\section{Granular duct structure and gene expression}

Rodent SMG are characterized by a highly specialized portion of the ductal system, the granular convoluted ducts (Fig. 3), whose secretory cells synthesize a variety of biologically active polypeptides, including nerve growth factor (NGF), renin and erythropoietin in the mouse, and epithelial growth factor (EGF) and kallikreins in the mouse and rat $(32,33)$. While the physiological functions of many granular duct-derived peptides have yet to be explored fully, the granular ducts themselves are an excellent system to study hormonal regulation of gene expression. The effects of diabetes on the granular ducts were first noted by Parhon et a! (34), and then independently by Liu and Lin $(6,7)$. Granular duct diameters were reduced in alloxan diabetic rats, and a similar decrease in granular duct size was observed in male $d b / d b m i c e$ (35). In female $d b / d b$ mice the granular ducts actually became more prominent. As the effects of diabetes on granular duct structure were generally ascribed to an impairment of the hypothalamic-pituitary axis (see below), masculini-zation of the SMG in female $d b / d b$ mice was thought to result from the effects of adrenal androgens, or from a defect in the conversion of ovarian androgens to estradiol. Despite the reduction in size, the overall granular duct cell morphology at the electron microscopical level (Fig. 3 B) was relatively unaffected in diabetic animals $(17,18)$. Diabetes also had a profound effect on the protein synthesis by mouse granular duct cells; the levels of EG F and NG F decreased by greater than $50 \%$ in streptozotocin-diabetic and $d b / d b$ mice (36-38). Protease activities, including those of glandular kallikrein and tonin in diabetic rats (Fig. 4) and renin in mice, were also decreased (16,32,39-41). Insulin treatment led to a complete recovery ofNGF, EGF and tissue kallikrein content in the mouse SMG. However, unlike acinar cell secretory proteins, the recovery of protein levels in the granular ducts required one week or more of insulin treatment. In the ca- se of some kallikrein-like proteases and tonin in the rat SMG, insulin appeared to have little, if any, effect over this time course. The induction of diabetes causes a reduction in the plasma concentrations of testosterone, thyroxine and growth hormone (42-44), and the recovery of normal plasma levels of these hormones occurs only with extended insulin treatment. Taken together these data support the hypothesis that the maintenance of granular duct gene expression is not directly dependent on insulin, and a brief review of the multihormonal regulation of granular duct structure and function is therefore warranted.

\section{- Multihormonal influences on granular duct gene expression}

Differences in granular duct structure between males and females have been described for a number of different species (32). The initial observations of a sexual dimorphism in the mouse SMG were reported independently by Lacassagne (45) and Fe-kete (46). The granular ducts were more prominent in male mice than in females, and this difference was dependent on the presence of androgen. However, androgens were not the only endocrine influences on the granular ducts by demonstrating that in male mice hypophysectomy had a greater effect than did castration (47). These results were made clear when it was shown that the development and maintenance of the granular ducts is dependent on the interaction of sexual, thyroid and adrenocorticoid hormones (48). Over the next three decades, a variety of experimental approaches confirmed and extended these findings, and the reader is encouraged to see the reviews published $(32,49)$.

Studies conducted in the late 1940's by Junqueira et $a$ ! (50) and later by Sreebny and Meyer (51) correlated the differences in granular duct histology and cytochemistry with the levels of protease activity in glandular extracts. Protease activity in female mice was significantly less than that in males, and in prepubertal mice enzymatic activity was very low and did not differ between males and females. In addition, protease content decreased in male SMG following castration, and increased in normal female and castrated male mice upon the administration of testosterone. These early studies established that androgens influence the levels of protease activity in the mouse SMG. Numerous studies have since demonstrated the effects of pituitary-dependent hormones on SMG proteases $(32,52,53)$. The sexual dichotomy between male and female rats is far less than that seen in the mouse. Not all proteases are equally affected under all conditions, but it is clear that protease gene expression in rodent SMG is regulated by a complex set of hormonal interactions. Receptors for androgens, estrogens, progesterone, thyroxine and glucocorticoids have been demonstrated in SMG (32), and while these hormones act predominantly at the level of mRNA transcription, they may also induce changes in translational efficiency. Additional!\}', hormonal re- 
Anderson

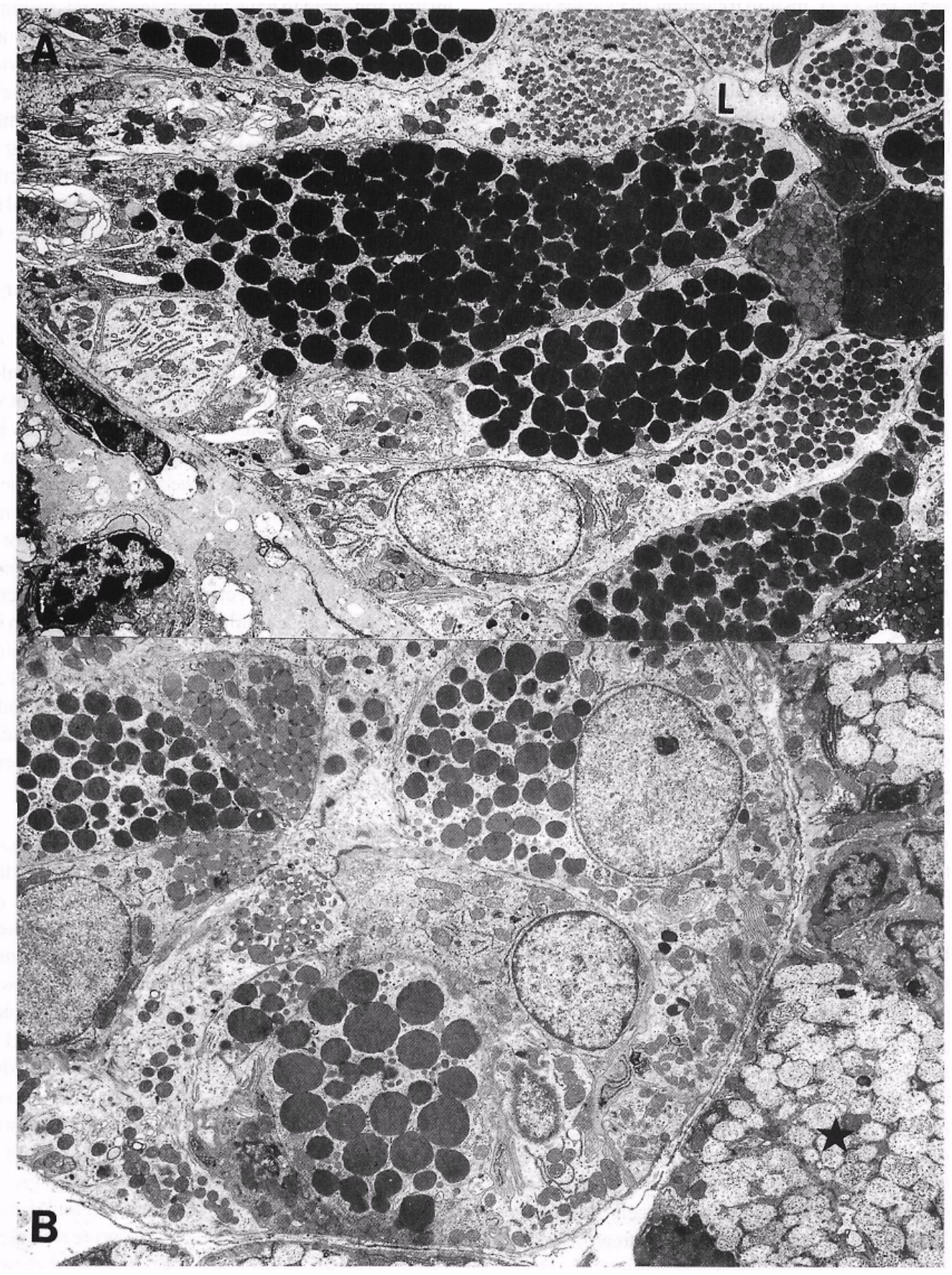

Figure 3. Electron micrograph of the sitbmandibiilar gland from a control rat. This represents a portion of a granular duct, consisting of columnar cells and containing variable numbers of secretory granules of varying electron density (A). Electron micrograph of the submandibiilar gland from a 3-week streptozotocin-diabetic rat. Although the morphology-of the duel cells appears to be relatively normal, the number of secretory granules seems to be less than in the control gland. A portion of an acinar cell (star) can also be seen (B). x 4260 (A), x 4460 (B). From Ref 13. 


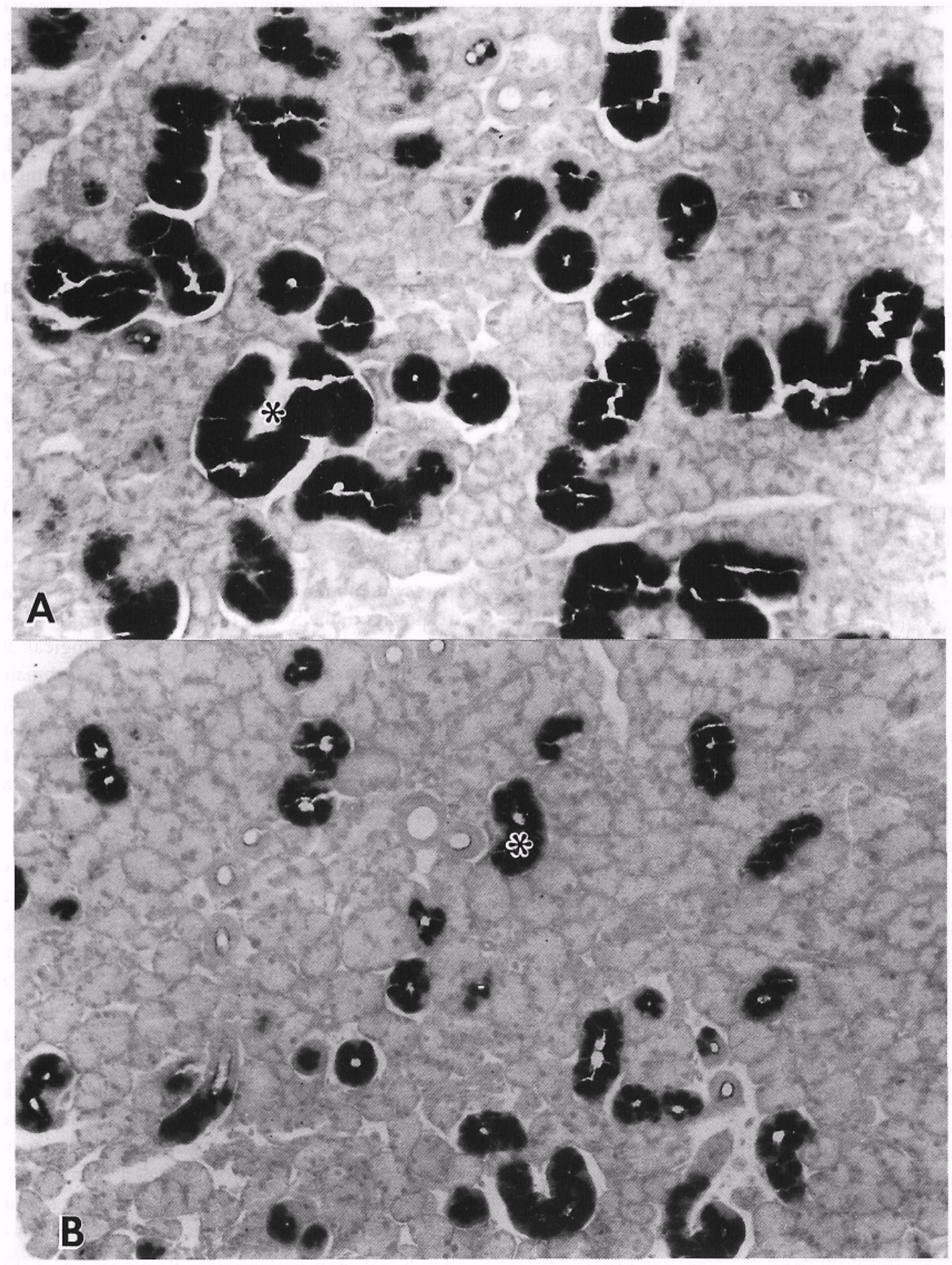

Figure 4. Light micrograph oj the submandibulai- gland from a control rat (A). Sections stained nvV/7 D-l'al-Leu-Arg-MNA and Fast Blue $B$ to demonstrate protease activity in the secretory granules of the granular ducts (asterisks). Note the intense reaction of the substrate over the granular ducts. Light micrograph of the submandibular gland from 3-month streptozotocin-diabetic rat (B). The diabetic gland shows a considerable reduction in substrate reactivity and in the number and size of the granular ducts (asterisks) compared with the control gland, x 200 (A, B). From Ref 13. 
gulation of SMG mRNA expression is quite tissue specific. For example, renin expression in the mouse SMG was enhanced by testosterone and diminished by castration, whereas in the kidneythe reverse was observed $(54,55)$. Thyroxine also upregula-ted the expression of renin mRNA inthe mouse SMG $(56,57)$, and the expression of kallikrein gene family members inthe rat SMG was androgen and thyroid-hormone dependent as well $(58,59)$. EGF and NGF expression in the mouse showed similar patterns of regulation by pituitary-dependent hormones (32). Each was present in greater concentrations in male than in female SMG. and castration and testosterone had opposing effects. Thyroxine and corticosteroids markedly increased the synthesis of EGF and NGF, but unlike the effects of testosterone, thyroid hormones preferential ly affected NGF expression (60). In general, the levels of $\mathrm{mRNA}^{\mathrm{EGF}}$ and $\mathrm{mRNA}^{\mathrm{NGF}}$ paral leled those of the polypeptides themselves, and hormonal control was tissue specific (61 -63). Finally, estrogens antagonized the effects of testosterone on EGF and protease synthesis $(64,65)$.

\section{- Neural regulation of parotid andsubmanclibular gland function in diabetes}

Because salivary gland exocrine function is almost entirely dependent on autonomic nerves, the question has naturally arisen as to whether salivary gland function in diabetes might be affected by alterations in the neural regulation of salivary secretion. Abnormalities in acinar or granular duct sensitivity to neurotransmitters, or the development of an autonomic nerve dysfunction per se would be expected to have profound effects on salivary gland physiology. Neuropathy is a common complication of diabetes, encompassing a number of clinical syndromes (66), and autonomic neuropathies, in particular, result in a variety of problems affecting the digestive, respiratory, urinary and reproductive systems. Chronic hyperglycaemia, which leads to the activation of the polyol pathway, the promotion of sorbitol and fructose accumulation, /Myo-inositol depletion and a slowing of nerve conduction velocity, appears to be a key factor in the development of diabetic neurpopathies. However, othermetabolic abnormalities, including protein glycation, su-peroxideradical formation, and altered amino acid and lipid metabolism, have been implicated.

In the parotid gland, sympathetic and parasympathetic nervestimulated salivary flow rates were reduced when compared with age-matched control animals (67). Parasympathetic impulses evoke salivary secretion largely through the activation of cholinergic receptors, and the impaired response could have reflected a decrease in the sensitivity of the acinar cells to acetylcho-line. However, no differences in the threshold doses formetha-choline orphysalaemin (a tachykinin analogue) were observed, and the volume of saliva secreted in response to each of these agonists was unaffected (68). It would appear, therefore, that the cellular mechanisms responsible for fluid secretion in the dia- betic parotid gland are intact, and that parasympathetic nerve dysfunction perse was responsible for the decrease in flow rate. Morphological evidence supported this hypothesis. Electron microscopy revealed a number of axonal abnormalities in the diabetic parotid gland (67). The interpretation of results obtained using continuous sympathetic stimulation in long-term diabetic rats was more problematical, but we have hypothesized that an exaggerated vasoconstriction, resulting in a dramatic reduction in parotid gland blood flow, was the cause of the diminished sympathetic response.

The secretion of amylase from diabetic parotid glands was also reduced in response to direct nerve stimulation of the sympathetic trunk, and the reduction in amylase secretion was correlated with a decrease in the extent of degranulation of the acinar cells (69). Together with data from pharmacological and reflex secretion studies $(70,71)$, these results suggested that diabetes leads either to a decrease in acinar cell responsiveness to $\mathrm{P}$ adrenoceptor stimulation, or to a decrease in the release of neurotransmitter from sympathetic nerve terminals. Despite initial reports to the contrary (14) and in distinct contrast to the parotid gland, recent studies have shown that direct sympathetic and parasympathetic nerve stimulation evokes normal secretory responses in the SMG (19). As in the parotid gland, therefore, neither the morphological nor hematological abnormalities present in diabetic animals appear to alter submandibular fluid secretion. However, long-term diabetes (6 months) did lead to a reduction in sympathetically-stimulated protein output and secretory granule release. Thus, the effects of diabetes on protein release and fluid mobilization would appear to be independent of one another.

The decrease in SMG protein output was probably due to several factors. First, the SMG contains two different secretory compartments, the acinar cells and the granular duct cells. Neither acinar cell size nor the relative volume density of acinar secretory granules were affected, but the granular duct compartment was significantly smaller in diabetic rats. In addition, there was a reduction in the volume density of secretory granules within the granular duct cells. Finally, sympathetic stimulation caused a smaller degranulation of both the acinar and granular duct cells in diabetic rats. This last observation was particularly intriguing. Sympathetic stimulation of acinar cells leads to a (3-adrenoceptor-mediated increase in cAMP, and subsequently to the exocytosis of secretory granules, whereas the secretion of polypeptides from the granular ducts is predominantly an a-adrenoceptor-mediated, $\mathrm{Ca}^{2}$ -dependent event. Nonetheless, the similar effects of diabetes on these two different intracellular signaling pathways indicate that some common mechanism may be involved. One possibility is that sympathetic nerve function was impaired in diabetic animals. No morphological evidence ofneuropathic changes in SMG nerves has been reported, but the levels of noradrenaline, cholineacetyl- 
transferase and acetylcholinesterase are altered in both diabetic mice and rats (72-74). However, since flow rates during sympathetic stimulation were unaffected, it seems reasonable to infer that nerve impulse formation and neurotransmitter release were normal. This same conclusion pertains to the parotid gland. In addition, changes in acetylcholinesterase histochemistry and catecholamine fluorescence in $d b / d b$ mice were found, and the differences were largely due to the effects of diabetes on the granular ducts, and a corresponding diminished neurotrophic effect of NGF (35,75). A second possibility is that the effects of diabetes on protein secretion were due to a change in adrenoceptor density or sensitivity. Thyroid hormones, for example, modulate SMG responses to a variety of neurotransmitters and neuropeptides (76-78), and circulating levels ofthyroid hormones are reduced in diabetic animals. The third possibility is that the changes in membrane fatty acid profiles might alter both cAMP metabolism, as well as the generation of intracellular signaling molecules such as inositol trisphosphate and diacylglycerol, from membrane phospholipids (79). Determining which, if any, of these hypotheses is correct awaits further investigation.

\section{SUBMANDIBULAR GLAND ENDOCRINE FUNCTIONS IN DIABETES MELLITUS}

- $\quad$ The exocrine function of the SMG has been studied extensively, but the precise physiological roles played by the polypeptides synthesized in the granular ducts remain to be fully explored. Numerous studies have shown that the circulat ing serum levels of many of these biologically active substan ces are derived in part from the SMG, and thus the salivary glands have been hypothesized to have an endocrine function and to participate in regulating a variety of physiological pro cesses, including reproductive tract function, neuroimmune responses and glucose homeostasis (80-83).

\section{- Submandibular gland as an endocrine organ}

Classically, endocrine cells and organs are characterized by their ability to sense changes in the internal environment, and as a consequence modulate the release of biologically active substances into the bloodstream. Under normal physiological conditions, endocrine cell function is regulated via both positive and negative feedback loops, thereby maintaining a relatively stable metabolic state. Such mechanisms have been classically termed homeostatic (83). With respect to salivary glands, responses to specific alterations in the levels of metabolites or other circulating substances remain speculative. Nonetheless, there appears to be a release of kallikreins, EGF, NGF and renin from SMG into the blood (84-86) under both resting and stimulated conditions, and experiments involving salivary gland ablation suggest that this constitutive release of biologically active polypeptides from the SMG contributes signifi- cantly to the regulation and maintenance of homeostasis (7983). SMG-deri ved EGF, for example, is thought to be necessary for normal liverregeneration after partial hepatectomy (87) and for male reproductive function (88), whereas sialoadenectomy increases the response to endotoxin (89).

\section{- Submandibular gland endocrine dysfunction and diabetic pathophysiology}

In contrast to homeostatic mechanisms, allostatic processes, which may be entirely inappropriate for normal function, become operative under pathological conditions (83). Under this allostatic model, changes in the exocrine or endocrine functions of salivary glands could contribute to the pathology associated with the onset of diabetes mellitus. The deficiencies in Submandibular EGF and NGF content were correlated with reductions in the plasma levels of these polypeptides, and the lower circulating levels of EFG andNGF have been hypothesized to play a role in the development of oligozoospermia (36) and diabetic neuropathy (37,3 8), respectively. SMG-derived NGF and EGF have also been proposed to contribute to systemic immu-noregulation and neuroendocrine function, and one could speculate that diabetic complications, such as poor wound healing, may be due in part to a disruption in this neuroimmunore-gulatory network (82). Alternatively, the effects of salivary constituents, which are inconsequential under normal circumstances, may be manifested in the disease state. No role for SMG-derived immunoreactive glucagon has been documented in carbohydrate homeostasis $(83,90)$. However, salivary gland hyperglycemic factors, such as glucagon, have been suggested to exacerbate the increase in blood glucose observed in both IDDM andNIDDM animal models (91,92). Chronic hyperglyce-mia has been hypothesized to be a major factor in the development of vascular and neural complications in diabetes $(66,93)$, and the inappropriate maintenance of increased serum glucose levels by extrapancreatic glucagon would therefore represent an allostatic load (83) contributing to the morbidity observed in diabetes mellitus.

\section{CONCLUSION}

- Saliva plays an important role in the protection of the oral cavity, and alterations in either salivary flow rate or compo sition are known to have dramatic effects on oral health. There is, however, a considerable divergence of opinion in the litera ture as to the extent, or even the existence, of changes in salivary composition and flow rate in insulin-treated, human diabetic patients. Nonetheless, over the past 40 years it has become clear that insulin and insulin insufficiency have both direct and indirect effects on the structure and function of the salivary glands. Insulin appears to play a direct role in the regulation of gene expression in the acinar cells, whereas its role in modulat- 
ing gene expression in the granular ducts of the rodent SMG is likely to be an indirect one, mediated via the effects of diabetes on pituitary-dependent hormones. Diabetes may also influence salivary gland function through altered autonomic nerve functionperse. Finally, the investigation of salivary gland structure and function in experimental diabetes has provided fundamental insights into the physiology of the salivary glands. Salivary glands, in turn, may be a valuable model system in which to study the development and pathophysiology of diabetes.

\section{ACKNOWLEDGMENTS}

- I wish to acknowledge my long-term collaboration with colleagues at King's College Hospital School of Dentistry, London, especially Professor John R. Garrettand DrGordon B. Proctor. The studies carried out in our laboratories were sup ported in part by grants from the Wellcome Foundation, Bur roughs Wellcome Fund, King's Medical Research Trust, School of Dentistry Research Fund (University of Washington) and NIH (DE 07391). The technical assistance of Miss Katherine Paterson and Mr Robert Hartley is gratefully acknowledged.

\section{REFERENCES}

1. Malaisse WJ. Alloxan toxicity to the pancreatic (3-cell. Biochem Pharmacol 1982; 31:3527-3534.

2. Rakeiten N, Rakieten ML, Nadkarni V. Studies on the diabetogenic action of streptozotocin (NSC-37917). Cancer Chemother Rep 1963; 29: 91-98.

3. Tannenbaum GS, Colle E, Gurd W, Wanamaker L. Dynamic time-course studies of the spontaneously diabetic BB Wistar rat. I. Longitudinal profiles of plasma growth hormone, insu-lin and glucose. Endocrinology 1981; 109: 1872-1879.

4. Stearns SB, Benzo CA. A longitudinal and comparative study of some structural and hormonal alterations in the endocrine pancreas of spontaneously diabetic and streptozotocin-induced diabetic mice. ActaAnat 1983; 115: 193203.

5. Hu Y, Nakagawa Y, Purushotham KR, Humphries-Beher MG. Functional changes in salivary glands of autoimmune disease prone NOD mice. AmJPhysiol 1992; 263: E607-E614.

6. Liu FTY, Lin HS. Role of insulin in body growth and the growth of salivary and endocrine glands in rats. JDent Res T969; 48:559-567.

7. Liu FTY, Lin HS. Relationship between insulin and growth hormone in growth and development of rat submandibular glands. ProcSocExp BiolMed 1969; 131: 175-179.

8. Anderson LC. Effects of alloxan diabetes and insulin in vivo on rat parotid gland. Am J Physio! 1983; 245: G431-G437.

9. Kirn SK, Cuzzort LM, Alien ED. Effects of age on diabetesand insulin-induced changes in pancreatic levels of ocamyiaseanditsmRNA. Mech AgeingDev 1991; 58: 151-161.
10. Kirn SK, Cuzzort LM, McKean RK, Alien ED. Effects of diabetes and insulin on a-amylase messenger RNA levels in rat parotid glands. J Dent Res 1990; 69: 1500-1504.

11. McPherson MA, Hales CN. Control of amylase biosynthesis and release in the parotid gland of the rat. Biochem J 1978; 176: 855-863.

12. Murakami H. Changes in activities of several enzymes for carbohydrate metabolism in the rat submaxillary gland in response to experimental diabetes and insulin treatment. $J$ Nihon UnivSch Dent 1974; 16: 91-94.

13. Anderson LC, Shapiro BL. The effect of alloxan diabetes and insulin in vivo on peroxidase activity in the rat submandibular gland. Archs Oral Biol 1979;24: 343-345.

14. Takai N, Uchihashi K, Yoshid Y, Kakudo Y. Salivational and histological damage of submandibular and sublingual glands in streptozotocin-induced diabetic rats. J Osaka Dent Univ 1983; 17: 65-72.

15. Reuterving C-O, Hagg E, Henriksson R, Holm J. Salivary glands in long-term alloxan diabetic rats. A quantitative light and electron microscopic study. Acta Pathol Microbiol Sca/7t/1986;95A: 131-136.

16. Chan K-M, Chao J, Proctor GB, Garrett JR, Shori DK, Anderson LC. Tissue kallikrein and tonin levels in submandibular glands of STZ-induced diabetic rats and the effects of insulin. Diabetes 1993; 42: 113-117.

17. Anderson LC, Suleiman AH, Garrett JR. Morphological effects of diabetes on the granular ducts and acini of the rat submandibular gland. Microsc Res Tech 1994; 27: 61-70.

18. Hand AR, Weiss RE. Effects of streptozotocin-induced diabetes on the rat parotid gland. Lab Invest 1984; 51: 429440.

19. Anderson LC, Garrett JR, Suleiman AH, Proctor GB, Chan $\mathrm{K}-\mathrm{M}$, Hartley R. In vivo secretory response of submandibular glands in streptozotocin-diabetic rats to sympathetic and parasympathetic nerve stimulation. Cell Tins Res 1993; 274:559-566.

20. Pinkstaff CA. Salivary glands, glycoconjugates and diabetes mellitus. EnrJMorphol 1996; 34: 187-190.

21. Anderson LC, Garrett JR. Lipid accumulation in the major salivary glands of streptozotocin-diabetic rats. Archs Oral S/o/1986;31:469-475.

22. Mortis PA, Prout RES, Proctor GB, Garrett JR, Anderson LC. Lipid analysis of the major salivary glands in streptozotocin-diabetic rats and the effects of insulin treatment. Archs Oral Biol 1992; 37:489-494.

23. Murthy VK, Bauman MD, Schipp JC. Regulation of triglyceride lipolysis in the perfused hearts of normal and diabetic rats. Diabetes 1983; 32: 718-722.

24. Stearns SB, Teperman HM, Tepperman J. Studies on the utilization and mobilization of lipid in skeletal muscles from streptozotocin-diabetic and control rats. J Lipid Res 1979; 20:654-662.

25. Nehemiah JL, Novikoff AB. Unusual lysosomes in hamster 
hepatocytes. ExpMolPathol 1974; 21: 398-423.

26. Anderson LC. Insulin-stimulated protein synthesis in submandibular acinar cells: Interactions with adrenergic and cholinergic agonists. Horn MetabolRes 1988; 20: 20-23.

27. Masi I, Pochiarri F, Szymczyk T. Metabolismo del glucosio nella ghindolta ssottomascellare di ratto in vitro. Ann Int Super Sanita (Rome) 1966; 2: 287-295.

28. Mickelborough ME. The metabolism of certain carbohydrate constituents of rat submaxillary gland. $J$ Dent Res 1967; 46: 82-86.

29. Szymczyk T, Swiatkowska B, Jachimowicz M. Effect of alloxan-diabetes on the content of sialic acids and activity of uridyltransferases in rat salivary glands. Acta Biochim Polon $\backslash 97 \bigwedge \backslash 8$ : 171-176.

30. Szymczyk T, Sadurska B. Participation of pancreatic hormones in the regulation of UDPG-pyrophosphorylase activity in the sublingual and submandibular salivary glands and liver in the rat. Arc/is Oral Biol 1978; 23: 631-638.

31. Kamad A, Kawamura M, Funato N, Nakagawa M, Nagsawa $\mathrm{S}$, Sakaki T. Changes in rat submandibular gland N-acetylp-glucosaminidase activity in streptozotocin-induced diabetes. J Osaka Dent Univ 1989;23: 15-27.

32. Gresik EW. The granular convoluted tubule (GCT) cell of rodent submandibular glands. Microsc Res Tech 1994; 27: 124.

33. Mori M, Takai Y, Kunikata M. Review: Biologically active peptides in the submandibular gland - role of the granular convoluted tubule. Acta Histochem Cytochem 1992; 25: 325-341.

34. Parhon CI, Babes A, Petra I. Endocrinologia glandelor salivare. In: Editura Academiei Republicii Populare Romine. Bucharest. 1957; 174-179.

35. Hanker JA, Carson KA, Yates PE, Preece JW, Doe DA, Ambrose WW et al. Cytochemical correlates of structural sexual dimorphism in glandular tissues of the mouse. Histochem istry 1980; 68: 99-118.

36. Noguchi S, Ohba Y, Oka T. Involvement of epidermal growth factor deficiency in pathogenesis of oligozoospermia in streptozotocin-induced mice. Endocrinology 1990; 127: 2136-2140.

37. Hellweg R, Hartung HD. Endogenous levels of nerve growth factor (NGF) are altered in experimental diabetes mellitus: a possible role for NGF in the pathogenesis of diabetic neuropathy. J Newosci Res 1990;26: 258-267.

38. Ordonez G, Femandez A, Perez R, Sotelo J. Low contents of nerve growth factor in serum and submaxillary gland of diabetic mice. A possible etiological element of diabetic neuropathy. JNeurol Sci 1994; 121: 163-166.

39. Jaffa AA, Rashid Z, Pratt J, Ash ford A, Bailey GS. A quantitative study of the levels of glandular kallikrein in normal and diabetic rats. Biochem Med $\backslash 984 ; 3$ 1: 42-46.

40. Sakamoto W, Yoshikawa K, Yokoyama A, Kohri M. Glandular kallikrein, renin and tonin in tissues of diabetic and hypertensive rats. JClin Chem Clin Biochem 1986; 24: 437-440.

41. Handa H, Sakurama S, Nakagawa S, Yasukouichi T, Sakamoto W, Izumi H. Glandular kallikrein, renin and angiotensin converting enzyme of diabetic and hypertensive rats. AdvExp Biol Med 1989; 247B: 443-448.

42. Murray FT, Orth J, Gunsalus G, Weisz J, Li B, Jefferson LS et al. The pituitary-testicular axis in the streptozotocindiabetic male rat: evidence for gonadotroph, Sertoli cell and Leydig cell dysfunction. Int JAndrology 1981; 4: 265-280.

43. Carlsson IMS, Clark RQ Skottner A, Robinson ICAF. Growth hormone and growth in diabetic rats: effects of insulin and insulin-like growth factor-1 infusions. JEndocrinol 1989; 122:661-670.

44. Zaninovich AA, Brown TJ, Boado R. Thyroxine metabolism in diabetic rats. Acta Endocrinol 1977; 86: 336-343.

45. Lacassagne A. Dimorphisme sexuel de la glande sousmaxillaire chez la souris. Comp RendSocSeanc Biol 1940; 133:180-181.

46. Fekete E. Histology. In: Snell GD, editor. Biology of the Laboratory Mouse. Blakiston, Philadephia. 1941; 89-167.

47. Lacassagne A, Chamorro A. Reaction a la testosterone de la glande sous-maxillaire, atrophee consecutivement a Phypophysectomie chez la souris. Comp Rend Soc Seanc 5/0/1940; 134:223.

48. Grad B, Leblond CP. The necessity of testis and thyroid hormones for the maintenance of the serous tubules of the submaxillary gland in the male rat. Endocrinology' 1949; 45: 250-266.

49. Chretien M. Action of testosterone on the differentiation and secretory activity of a target organ: The submaxillary gland of the mouse. Int Rev Cytol 1977; 50: 333-396.

50. Junqueira LC, Fajer A, Rabinovitch M, Frankenthal L. Biochemical and histochemical observations on the sexual dimorphism of mice submaxillary glands. J Cell Comp Physio/1949-34: 129-158.

51. Sreebny LM, Meyer J. Hormones, inanition and salivary glands. In: Sreenby LM editor. Salivary Glands and Their Secretions. Pergamon Press, Oxford. 1964; 83-103.

52. Chao J, Margolius HS. Differential effects of testosterone, thyroxine, and cortisol on rat submandibular gland versus renal kallikrein. Endocrinology' 1983; 113:2221-2225.

53. Garrett JR, Proctor GB, Shori DK, Suleiman AM, Clarke GA. Sexual dimorphism of rat submandibular salivary proteinase: A histochemical and biochemical study using oligopeptide substrates. A eta Histochem Cytochem $\backslash 992 ; 25: 23-30$.

54. Dzau VJ, Brody T, Ellison KE, Pratt RE, Ingelfmger JR. Tissue-specific regulation of renin expression in the mouse. Hypertension 1987; 9: III36-I1I41.

55. Wagner D, Metzger R, Paul M, Ludwig G, Suzuki F, Takahashi $\mathrm{S}$ et al. Androgen dependence and tissue specificity of renin messenger RNA expression in mice. $J$ Hypertens 1990; 8:45-52. 
56. Tronik D, Rougeon F. Thyroxine and testosterone transcriptionally regulate renin gene expression in submaxillary gland of normal and transgenic mice carrying extra copies of the Ren2 gene. FEBS Lett 1988; 234: 336-340.

57. McGowan RA, Gross KW, Wilson CM. Effect of androgen and thyroid hormones on renin-1 messenger ribonucleic acid levels in mouse submandibular gland. Mol Cell Endocrinol 1988; 56:271-276.

58. Clements JA, Matheson BA, Wines DR, Brady JM, Mac Donald RJ, Funder JW. Androgen dependence of specific kallikrein gene family members expressed in rat prostate. $J$ BiolChem 1988; 263:16132-16137.

59. Clements JA, Matheson BA, Funder JW. Tissue-specific regulation of the expression of rat kallikrein gene family members by thyroid hormones. Biochem J1990; 267: 745750 .

60. Walker P, Weichsel Jr ME, Hoath SB, Poland RE, Fisher DA. Effect of thyroxine, testosterone, and corticosteroid on nerve growth factor (NGF) and epidermal growth factor (EGF) concentrations in adult female mouse submaxillary gland: dissociation of NGF and EGF responses. Endocrinology 1981; 109: 582-587.

61. Gubits RM, Shaw PA, GresikEW, Onetti-MudaA, BarkaT. Epidermal growth factor gene expression is regulated differentially in mouse kidney and submandibular gland. Endocrinology 1986:119: 1382-1387.

62. Kasayama S, Ohba Y, Oka T. Expression of the epidermal growth factor gene in mouse lacrimal gland: comparison with that in the submandibular gland and kidney. $J$ Mol Endocrinol 1990; 4: 31-36.

63. Fujieda M, Murata Y, Hayashi H, Kambe F, MatsuiN, Seo H. Effect of thyroid hormone on epidermal growth factor gene expression in mouse submandibular gland. Endocrinology' 1993; 132: 121-125.

64. TuomelaT, Miettinen P, ViinikkaL, Perheentupa J. Estrogenandrogen antagonism in the regulation of epidermal growth factor in mouse submandibular salivary glands and kidney. LifeSci199Q;47: 1925-1932.

65. Clements JA, Matheson BA, MacDonald RJ, Funder JW. Oestrogen administration and the expression of the kallikrein gene family in the rat submandibular gland. $J$ Steroid Biochem 1990; 35: 55-60.

66. Greene DA, Sima AAF, Stevens MJ, Feldman E, Lattimer SA. Complications: neuropathy, pathogenic considerations. Diabetes Care 1991; 15: 1902-1925.

67. Anderson EC, Garrett JR, Thulin A, Proctor GB. Effects of streptozotocin-induced diabetes on sympathetic and parasympathetic stimulation of parotid salivary gland function in rats. Diabetes $\backslash 889$; 38: 1381-1389.

68. Anderson LC. Parotid gland function in streptozotocindiabetic rats. J Dent Res 1987; 66:425-429.

69. Anderson EC, Garrett JR, Proctor GB. Morphological effects of sympathetic nerve stimulation on rat parotid glands 3-4 weeks after the induction of streptozotocin diabetes. Archs OralBiol 1990; 35: 829-838.

70. Kurahashi M, Inomata K. Amylase secretion by parotid glands and pancreas of diabetic rats during feeding. Am J Physiol 1982; 254: G878-G882.

71. Kurahashi M, Nakamura H, Inomata K. Effect of acute diabetes on isoproterenol-induced amylase secretory cycle in rat parotid glands. In: Case RM. Lingard JM, Young JA, editors. Secretion: Mechanisms andControl. Manchester University Press, Manchester. 1984; 243-247.

72. Anderson EC, Garrett JR. The effects of streptozotocininduced diabetes on norepinephrine and cholinergic enzyme activities in rat parotid and submandibular glands. Archs OralBioll994;39: 91-97.

73. Giachetti A. The functional state of sympathetic nerves in spontaneously diabetic mice. Diabetes 1978; 27: 969-974.

74. Murai S, Saito H, Masuda Y, Nakamura K, Michijri S, Itoh T. Effects of short-term (2 weeks) streptozotocin-induced diabetes on acetylcholine and noradrenaline in the salivary glands and secretory responses to cholinergic and adrenergic sialogogues in mice. Archs OralBiol 1996; 41: 673-677'.

75. Carson K.A, Sar M, Hanker JS. Immunocytochemical demonstration of nerve growth factor and histofluorescence of catecholaminergic nerves in the salivary glands of diabetic mice. Histochem $\wedge$ 982:14:35-48.

76. Tumilasci OR, Houssay AB, Paz C V, Sosto NE, Varela V. Influence of thyroid function upon "substance $\mathrm{P}$ " induced secretion of saliva by submaxillary glands. Harm Metab fowl 986; 18:234-237.

77. Tumilasci OR, Houssay AB, Sosto NE, Paz C V, Varela V. Thyroid hormone modulation of VIP's induced salivary secretion in the submaxillary glands of rats. $J$ Endocrinol Invest $1986: 9:$ 51-55.

78. Tumilaci OR, Medina $\mathrm{CH}$, Camper $\mathrm{CH}$, Houssay AB. Effects of thyroid function on submaxillary gland sensitivity to autonomic nervous drugs. J Endocrinol Invest 1982; 5: 511.

79. Ahmad SN, A lam SQ, Alam BS. Fatty acid incorporation into membranes of dispersed rat submandibular salivary gland cells and their effect on adenylate cyclase activity. Arcl-isOralBioN990;35: 878-883.

80. Ogata T. The internal secretion of salivary gland. Endocrinol Jap 1955; 2: 247-261.

81. BoyerR, Jame F, Arancibia S. Une fonction non exocrine de laglandesous-maxi\aYe. Ann d'Endocrino!1991; 52: 307322 .

82. Sabbadini E, Berczi I. The submandibular gland: a key organ in the neuro-immuno-regulatory network? Neuroimnnmomodulation 1995; 2: 184-202.

83. Mathison R. The submandibular glands: A role in homeostasis andallostasis. BiomedRev 1995; 4: 61-69.

84. Garrett JR, Chao J. Proctor GB, Wang C, Zhang XS. Chan K-M et al. Influences of secretorv activities in rat subman- 
dibular glands on tissue kallikrein circulating in the blood. Exp Physio/1995; 80:429-440.

85. Murphy RA, Watson AY, Matz J, Frossmann WG. The mouse submandibular gland: An exocrine organ for growth factors. J Hixtochem Cytochem 1980; 28: 890-902.

86. Aloe L, Alleva E, Bohm A, Levi-Montalcini R. Aggressive behavior induces release of nerve growth factor from mouse salivary gland into the blood stream. Proc Natl AcadSci USA 1986:83:6184-6187.

87. Jones DE Jr, Tran-Patterson R, Cui D-M, Davin D, Estell KP, Miller DM. Epidermal growth factor secreted from the salivary gland is necessary for liver regeneration. Am J Physio! \995:268: G872-G878.

88. Liu A, Flores C, Kinkead T, Carboni AA, Menon, M, Seethalakshmi L. Effects of sialoadenectomy and epidermal growth factor on testicular function of sexually mature mice. J Urol 1994; 152: 554-561.
89. Mathison RD, Befus D, Davison JS. Removal of the submandibular glands increases the acute hypotensive response to endotoxin. Circ Shock 1993; 39: 52-58.

90. Smith S, Mazur A, Voyles N, Bhathena S, Recant L. Is submaxillary gland immunoreactive glucagon important in carbohydrate homeostasis? Metabolism 1979:28: 343-347.

91. Boros I, Keszler P. Prevention of hyperglycaemia in streptozotocin-treated rats by submandibular gland ablation. Harm MetabolRes 1989; 21: 460-461.

92. Kirn YT, Hoshino K, Hyodo T, Friesen HG, Nahynybida LJ. Hyperglycemic factor in submandibular glands and its etiological relations to diabetes mellitus. Endocrine/ Jap 1979; 26:487-494.

93. Winegrad A1. Does a common mechanism induce the diverse complications of diabetes. Diabetes 1987; 36: 396406. 